\title{
Identification of biodegradation products of biphenyl and 2,3-dihydroxybiphenyl (2,3-DHB)
}

\author{
Slavomíra Murínováa,, Katarína Dercováa, \\ Peter Tarábek ${ }^{\mathrm{b}}$, Peter Tölgyessy \\ ${ }^{a}$ Slovak University of Technology, Faculty of Chemical and Food Technology \\ Institute of Biotechnology and Food Science, Department of Biochemical Technology, \\ Radlinského 9, 81237 Bratislava, Slovakia \\ ${ }^{b}$ Water Research Institute, Nábrežie arm. gen. L. Svobodu 5, 81249 Bratislava, Slovakia \\ slavomira.murinova@gmail.com
}

\begin{abstract}
We investigated the degradation of biphenyl and identified main degradation products. Biphenyl and 2,3-dihydroxybiphenyl (2,3-DHB) was added to cultivation media to identify whole collection of degradation products of four bacterial strains isolated from long-term PCB contaminated soil (Alcaligenes xylosoxidans and Pseudomonas stutzeri) and long-term PCB contaminated sediment (Ochrobactrum anthropi and Pseudomonas veronii). Cultivation flasks were processed in different time after inoculation to determine biphenyl fission rate. Alcaligenes xylosoxidans was revealed as the most appropriate strain for bioremediation process with the highest biphenyl transformation rate. Biphenyl degradation led to the formation of benzoic acid. However, as the presence of 2-hydroxy-6-oxo-6-phenylhex-2,4-dienoic acid (HOPDA) was not confirmed, the transformation pathway common for many other bacteria is probably modified.
\end{abstract}

Keywords: bacteria, biodegradation, biphenyl, degradation products, 2,3-dihydroxybiphenyl

\section{Introduction}

Hydrophobic organic pollutants are a serious problem to the environment. They tend to persist in the environment without changes for a long time. Most of them are toxic to living organisms. They low water solubility hampers its degradation by most microorganisms (Brázová et al. 2012). Biphenyl is an aromatic hydrocarbon generally used in polychlorinated biphenyls (PCB) production. It is solid at room temperature with water solubility $7.5 \mathrm{mg} . \mathrm{l}^{-1}$ and $\log \mathrm{K}_{\mathrm{ow}}$ 4.09. The former producer (Chemko Strážske) of the commercial mixtures of PCBs (Delor 103, Delor 106, and Hydelor) in Slovakia manufactured altogether approximately 21,500 tons of these chemicals (Dercová et al. 2008). A huge amount of liquid waste from this production containing high concentration of biphenyl and terpenyl was released to the Strážsky canal that resulted in serious contamination of soil and river sediments (Langer et al. 2013). Biodegradation of such contaminats by bacteria, bioremediation, is promising alternative to more expansive and dangerous physico-chemical technologies. It uses bioaugmentation and biostimulation strategies which mean the introduction of specific degradable strains or consortia of microorganisms and introduction of nutrients and oxygen to improve biodegradation of particular contaminants (Mrozik and Piotrowska-Seget 2010). Biphenyl is a non-chlorinated structural analogue of PCBs. Therefore, the degradation pathway should be similar for both types of compounds (Syl- vestre 1995). Microbial degradation of biphenyl is present under aerobic condition (Fig. 1) (Sondossi et al. 1992; Chong et al. 2012). In the environment, biphenyl can be transformed into benzoic acid or catechol by appropriate aerobic bacteria via upper oxidative breakdown pathway (Abramowicz 1990). This pathway seems to be similar in most aerobic microorganisms and consist of a series of reactions catalyzed by biphenyl-2,3-dioxygenase (BphA), dihydrodiol dehydrogenase (BphB), 2,3-dihydroxybiphenyl dioxygenase (BphC), 2-hydroxyl-6-oxo6-phenylhexa-2,4-dienoic acid hydrolase (BphD), 2-hydroxypenta-2,4-dienoate hydratase (BphE), 4-hydroxy-2-oxovalerate aldolase (BphF), and acetaldehyde dehydrogenase (BphG) (Seeger 1995; Ohtsubo et al. 2000; Sierra et al. 2003). The BphA enzyme converts biphenyl to dihydrodiol by the incorporation of two oxygen atoms into biphenyl ring (Komancová et al. 2003). This step is followed with the transformation of dihydrodiol to 2,3dihydroxybiphenyl by $\mathrm{BphB}$ and transformation of 2,3-dihydroxybiphenyl into 2-hydroxy-6-oxo-6phenylhexa-2,4-dienoic acid (HOPDA). BphD converts HOPDA into two molecules, benzoic acid and 2-hydroxypenta-2,4-dienoate (Furukawa et al. 1994; Tříska et al. 2004). Benzoic acid is end product that is usually not degraded by the same bacteria. However, it could be transformed by other microorganism which posses benzoic catabolic enzymes (Vrana et al. 1996). 2-hydroxypenta-2,4-dienoate could be converted into acetyl CoA and pyruvate by BphE, BphF and BphD (Ohtsubo et al. 2000). 


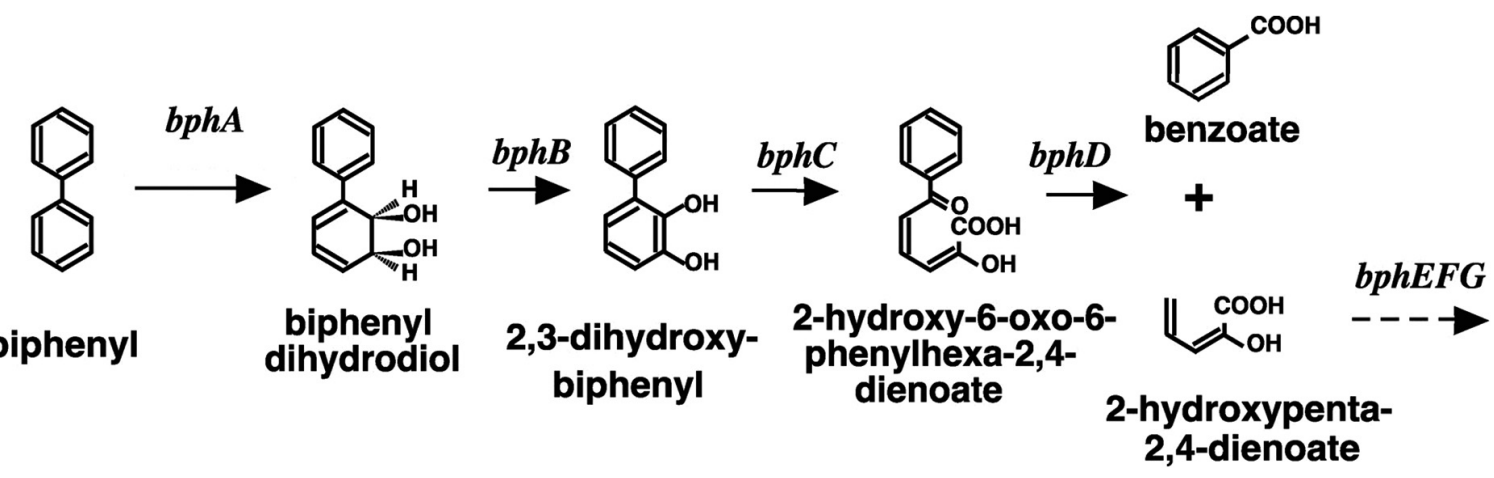

Fig. 1. Proposed aerobic metabolic pathway of biphenyl degradation by bacterial strains (Ohtsubo et al. 2000; Furukawa and Fujihara 2008).

Some microorganisms possess biphenyl-3,4-dioxygenase together or instead of $\mathrm{BphA}$. The transformation of biphenyl with this enzyme usually resulted into formation of acetophenone (Yagi and Sudo 1980; Bedard et al. 1987). Complete degradation pathway with biphenyl-3,4-dioxygenase has not been studied in details yet.

In this study we effort to investigate main degradation products of biphenyl cleavage by four bacterial strains able to degrade PCBs (Zorádová-Murínová et al. 2012) and find out whether the studied isolates follow common degradation pathway of biphenyl/ PCBs. Another aim was to determine the rate of biphenyl fission to evaluate the most promising bacterial strain for further biodegradation experiments and possible application in bioremediation technologies to clean-up the contaminated sites.

\section{Materials and methods}

\section{Bacterial strains}

Bacterial strains used in the study were isolated from long-term PCB contaminated area. Alcaligenes xylosoxidans and Pseudomonas stutzeri were obtained from PCB-contaminated soil by enrichment in mineral medium with biphenyl according to Dercová et al. (1996). Ochrobactrum anthropi and Pseudomonas veronii were isolated from contaminated sediment sampled from Strážsky canal according methods described by Dudášová et al. (2014). All abovementioned strains were identified and kept under the mode "safety storage" without number assignment at the Czech Collection of Microorganisms (Masaryk University, Brno, Czech Republic).

\section{Chemicals}

Biphenyl and n-hexane (Merck, Germany), 2,3dihydroxybiphenyl (Sigma-Aldrich, USA), benzoic acid (SigmaAldrich), metanol (Mikrochem, Slovak Republic), hydrochloric acid, dichlormetane, and formic acid (Merck, Germany), culture broth No. 2 (Imuna, Slovak Republic) and other chemicals for minimal mineral medium (MM medium) (Lachema, Czech Republic) were used in the degradation experiments.

\section{Design of experiments for degradation products identification}

Bacterial inocula were prepared in growth medium on a rotary shaker $180 \mathrm{rpm}$ for $48 \mathrm{~h}$ at $28^{\circ} \mathrm{C}$. Biomass was harvested by centrifugation, washed two times with saline solution and added to the $100 \mathrm{ml}$ of MM medium at a final concentration of $1 \mathrm{~g} \cdot \mathrm{l}^{-1}$. The MM medium consisted of $1.0 \mathrm{~g} . \mathrm{l}^{-1}\left(\mathrm{NH}_{4}\right)_{2} \mathrm{SO}_{4}$, 2.7 g. l $^{-1} \mathrm{KH}_{2} \mathrm{PO}_{4}, 5.2$ g. l $^{-1} \mathrm{NaHPO}_{4} \cdot 2 \mathrm{H}_{2} \mathrm{O}, 0.2$ g. l $^{-1}$ $\begin{array}{llllll}\mathrm{MgSO}_{4} \cdot 7 & \mathrm{H}_{2} \mathrm{O}, & 0.01 & \mathrm{~g} . \mathrm{l}^{-1} & \mathrm{FeSO}_{4} \cdot 7 & \mathrm{H}_{2} \mathrm{O} \text {, and }\end{array}$ $0.03 \mathrm{~g} . \mathrm{l}^{-1} \mathrm{Ca}\left(\mathrm{NO}_{3}\right)_{2} \cdot 4 \mathrm{H}_{2} \mathrm{O}$.

Ten $\mathrm{mg}$ of biphenyl or 2,3-dihydroxybiphenyl (2,3-DHB) was added as sole carbon and energy source. All flasks were incubated on a rotary shaker at $180 \mathrm{rpm}$ and $28^{\circ} \mathrm{C}$ in the dark for $1 \mathrm{~h}$ and $24 \mathrm{~h}$. A control experiment containing only bacterial strain in MM medium was run in parallel.

\section{Solid phase extraction (SPE)}

Cultivation flasks were taken from a rotary shaker and kept in ultrasonic bath for $10 \mathrm{~min}$. After sonification the total flask content was centrifuged at $6600 \mathrm{rpm}$ (RCF 5000) for $10 \mathrm{~min}$, supernatant was acidified with hydrochloric acid to $\mathrm{pH} 2$, and extracted with solid phase extraction columns LiChrolut EN (Merck, Germany) according to Tříska et al. (2004). Methanol was evaporated to the final volume of $2 \mathrm{ml}$. One half of the sample was used for LC-MS and another for GC-MS analyses. Methanol was completely evaporated from both samples. The metabolites used for GC-MS analysis were dissolved in $200 \mu \mathrm{l}$ of dichloromethane and subsequently analyzed. The metabolites for LC-MS analysis were dissolved in $1.5 \mathrm{ml}$ of methanol:water $(20: 80 \mathrm{v} / \mathrm{v})$ with $0.01 \%$ formic acid (pH 3.16) and sonicated for $10 \mathrm{~min}$ at ambient temperature. Then, the solutions were transferred to polypropylene microtubes (Eppendorf, Ger- 
many) and centrifuged for $20 \mathrm{~min}$ at $10000 \mathrm{rpm}$ ( $\mathrm{RCF} \sim 4500)$ to remove particulate matter before injection into the LC-MS system.

\section{Analytical methods for the identification of degrada- tion products}

The extract of degradation products was analyzed by GC using a Hewlett-Packard 6890GC-5972 MS system (Palo Alto, CA, USA) equipped with a split/splitless inlet. For the separation of analytes a $30 \mathrm{~m} \times 0.25 \mathrm{~mm}$ I.D. fused silica HP-5MS capillary column with a film thickness of $0.25 \mu \mathrm{m}$ from Agilent Technologies (Santa Clara, CA, USA) was used. The GC was run for $1 \mathrm{~min}$ with pulsed splitless injection at 29 psi and oven temperature programmed from $60{ }^{\circ} \mathrm{C}(1 \mathrm{~min})$ to $125^{\circ} \mathrm{C}$ at $25^{\circ} \mathrm{C}$. $\mathrm{min}^{-1}$ and then to $250^{\circ} \mathrm{C}(18.07 \mathrm{~min})$ at $15^{\circ} \mathrm{C} \cdot \mathrm{min}^{-1}$. The temperature of the inlet was $250{ }^{\circ} \mathrm{C}$. Helium was used as a carrier gas with a constant flow rate of $1.2 \mathrm{ml} \cdot \mathrm{min}^{-1}$.

Compounds separated by gas chromatography were detected by MS operating in full scan mode in the range from $\mathrm{m} / \mathrm{z} 45$ to 500 at scan rate of 1.68 scans. $^{-1}$. Temperatures of the MS ion source and of the GC-MS interface were $182^{\circ} \mathrm{C}$ and $280^{\circ} \mathrm{C}$, respectively. Identification of mass spectra of the detected compounds was carried out by computer matching against an Agilent Wiley7n mass spectra library (Agilent Technologies, USA).

The SPE extracts were also analyzed by Agilent Technologies 1200 Series LC with a reverse-phase column phenomenex KINETEX ${ }^{\mathrm{TM}}$ C18 $(100 \times 2.1 \mathrm{~mm}$, $2.6 \mu \mathrm{m})$ maintained at a temperature of $40{ }^{\circ} \mathrm{C}$. Methanol:water $(20: 80 \mathrm{v} / \mathrm{v})$ with $0.01 \%$ formic acid (pH 3.16) (A) and methanol with $0.01 \%$ formic acid (B) were used as mobile phases. The gradient was $100 \%$ of $\mathrm{A}(0 \mathrm{~min})$ and $5 \%$ of $\mathrm{A}$ and $95 \%$ of $\mathrm{B}(20 \mathrm{~min})$ at a flow rate $0.25 \mathrm{ml} \cdot \mathrm{min}^{-1}$. Agilent Technologies XCT Plus ion trap was used for the MS detection. Detection conditions were as follows: electrospray ionization (ESI) (positive and negative), nebulizer pressure: 50 psi, dry gas $\left(\mathrm{N}_{2}\right)$ flow rate: 101 . $\mathrm{min}^{-1}$ and temperature $350{ }^{\circ} \mathrm{C}$, ion optics voltages and trap drive: Smart Parameter Setting, maximum accumulation time: $100 \mathrm{~ms}$. Helium at a pressure of $6 \times 10^{-6}$ mbar was used as a collision gas within the ion trap.

The MS/MS spectra were recorded for each transition either in single ion monitoring (SIM) or multiple reaction monitoring (MRM) mode with cut-off mass and fragmentation amplitude adjusted to maximize the yields of the fragments.

For the compounds, for which no sufficient fragmentation could be achieved (benzoic acid, negative ion mode), pseudo-molecular ion $\mathrm{m} / \mathrm{z}$ along with retention time were used for identification.

\section{Statistic evaluation}

All experiments ran in triplicate to provide statistic assessment. The degradation products measured with GG-MS were identified in all parallels. The standard deviation of LC-MS results did not exceeded $20 \%$ of particular value.

\section{Results and discussion}

The purpose of this study was to investigate the biphenyl (non-chlorinated analogue of toxic PCBs) transformation by four bacterial isolates and to identify biphenyl degradation products. The differences in concentration of degradation products of biphenyl (2,3-DHB and benzoic acid) and 2,3-DHB (benzoic acid) by strains were measured after $1 \mathrm{~h}$ and $24 \mathrm{~h}$ after inoculation. Fig. 2 describes bacterial growth on $10 \mathrm{mg}$ of biphenyl within $48 \mathrm{~h}$ from inoculation. According to results it could be concluded that none of bacterial strains used in this study is able to grow on $10 \mathrm{mg}$ of biphenyl. A small increase of biomass observed for $O$. anthropi and $P$. veronii $10-15 \mathrm{~h}$ from the inoculation is statistically non-significant. Two possibility explanations could be deduced from our results. First, bacterial strains can only co-metabolize biphenyl while growing on other substrate. Second, biphenyl amount $10 \mathrm{mg}$ is not sufficient to provide bacterial growth. Higher amount of biphenyl may serve as appropriate growth substrate. However, we suppose that first deduction is valid. According to our previous study (Murínová et al. 2014) these bacterial strains were not able to grow on different concentration of biphenyl added together with PCBs.

Metabolites produced from biphenyl degradation in the presence of bacterial degraders were monitored by GC-MS as well as by LC-MS techniques. The total ion current chromatogram of the main metabolites of A.xylosoxidans culture extract after 24-hour cultivation in the presence of biphenyl or 2,3-DHB is presented in Fig. 3.

Based on the mass spectra and the data suggested by MS library, the 2-hydroxybiphenyl, 3-hydroxybiphenyl, and traces of 4-hydroxybiphenyl were identified in the extract from biphenyl transformation (Fig. 3-1). Benzoic acid was identified on the basis of comparison of the retention time with the standard (RT $6.4 \mathrm{~min}$ ) and according to the mass spectrum. This acid was formed also when 2,3DHB was added instead of biphenyl. The results obtained from the GC-MS analysis (Fig. 3-2) showed the presence of phenylmaleic anhydride, 4-phenyl4-cyclopentene-1,3-dione, 4-hydroxy-benzeneacetic acid methylester, and benzeneacetic acid.

The results obtained from the experiments with $O$. anthropi were similar to those described above except 


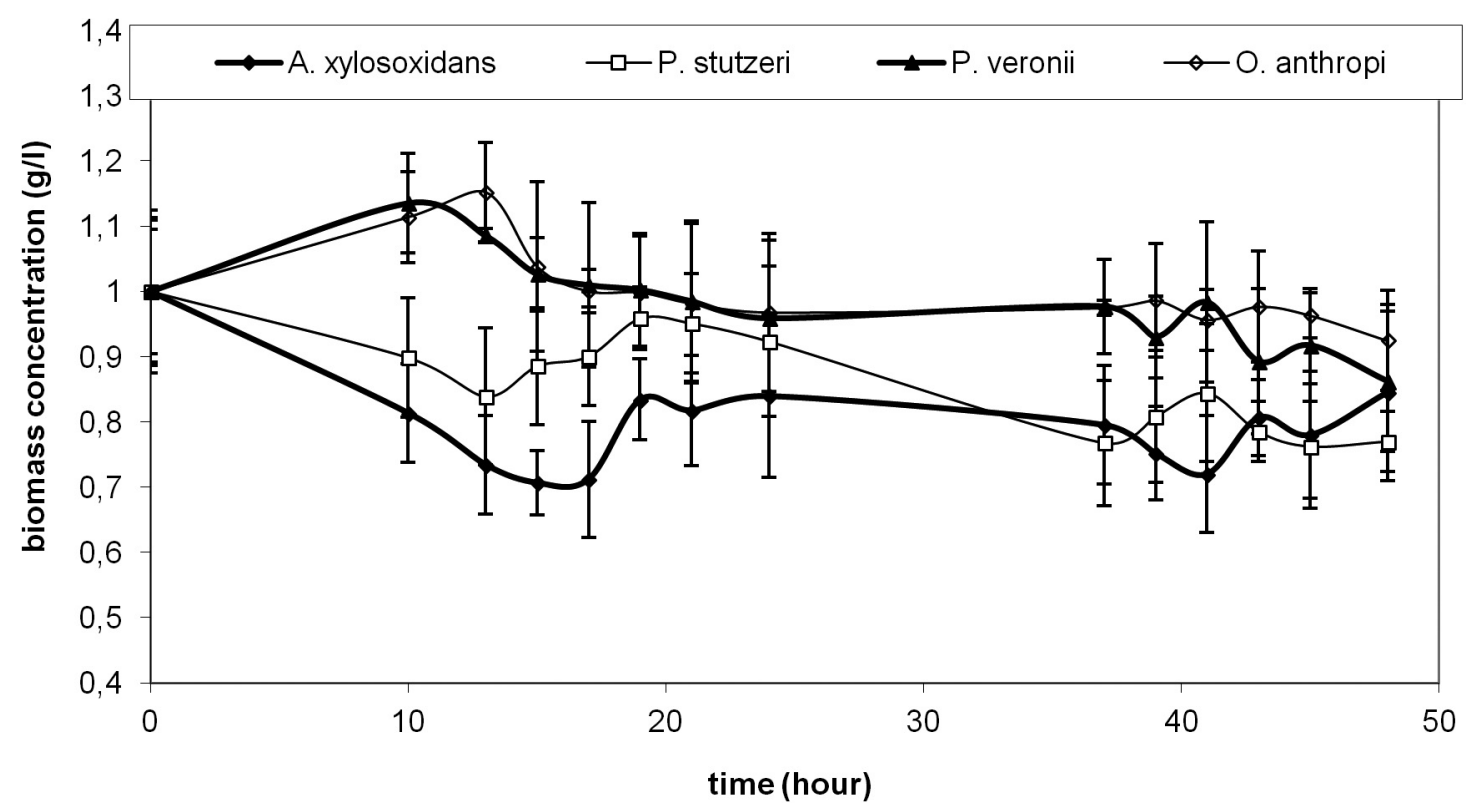

Fig. 2. Growth curves of four bacterial strains A. xylosoxidans and P. stutzeri isolated from a long-term contaminated soil and $O$. anthropi and $P$. veronii isolated from a long-term contaminated sediment in the presence of $10 \mathrm{mg}$ biphenyl as sole carbon source.

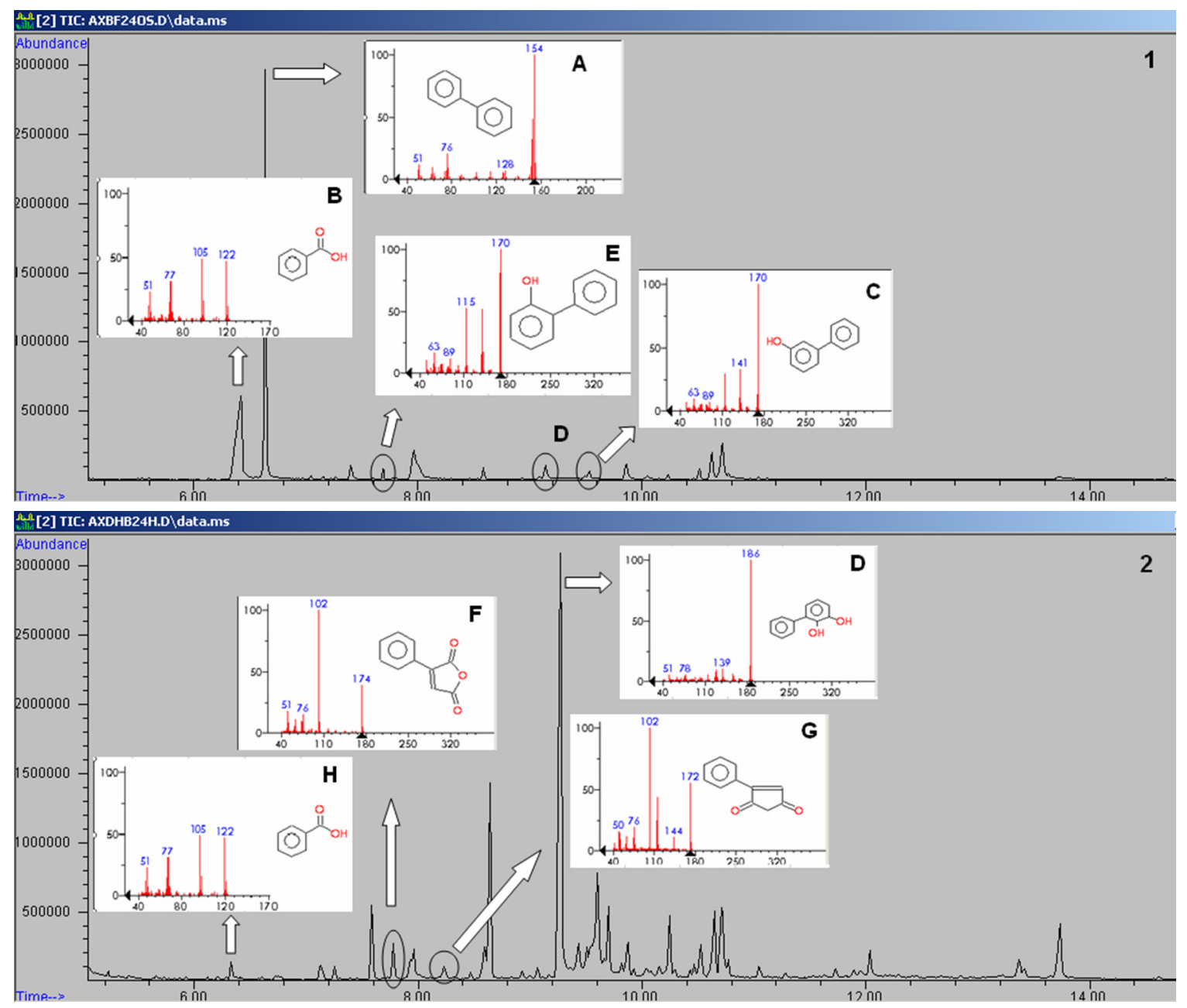

Fig. 3. Total ion GC-MS chromatogram of the main metabolites of biphenyl (1) and 2,3-DHB (2) produced by A. xylosoxidans. A - biphenyl; B, H - benzoic acid; C - 3-hydroxybiphenyl; D - 2,3-dihydroxybiphenyl; E - 2-hydroxybiphenyl; F - phenylmaleic anhydride; G - 4-phenyl-4-cyclopentene-1,3-dione. 
where 2-hydroxyacetophenone and acetophenone were present instead of 4-hydroxy-benzeneacetic acid methylester (data not shown). Komancová et al. (2003) also described the formation of chloroacetophenone from 2,2,5-trichlorobiphenyl by Pseudomonassp. 2 and declared that this degradation product was formed as a result of 3,4-dioxygenase pathway. Similar results were described by other authors (Bedard et al. 1987; Petrić et al. 2007).

Both Pseudomonas strains produced similar degradation products as $A$. xylosoxidans. Interestingly, phenylmalonic acid was detected with these two bacterial strains. This compound contains two carboxyl groups and is not present generally in biphenyl/PCB degradation pathway.

The main 2,3-dioxygenase degradation metacleavage product HOPDA (Tř́ska et al. 2004; Field and Sierra-Alvarez 2008) was not detected similarly as in Tu et al. (2011) experiment. 4-phenyl-4-cyclopentene-1,3-dione and phenylmaleic anhydride were identified instead. These intermediates are structurally similar to that described by Yagi and Sudo (1980). Other interesting degradation product, 4-hydroxy- benzeneacetic acid methylester, was formed by $A$. xylosoxidans most likely from 4-hydroxybiphenyl. The degradation product of PCB congeners could be similar due to structure similarity and the same degradation pathway Seeger et al. (1995).

The rate of formation of two biphenyl degradation products 2,3-DHB and benzoic acid (Fig. 4) was monitored by LC-MS. Benzoic acid/chlorobenzoic acids are considered as a dead-end metabolic products of biphenyl/PCBs degradation (Vrana et al. 1996; Tříska et al. 2004). Bacteria able to degrade biphenyl/PCBs do not usually posses genes for the degradation of benzoic acid/chlorobenzoic acids. Therefore these products cumulate in the environment after biphenyl/PCBs degradation and indicate the degradation rate.

Fig. 5 shows biphenyl transformation after $1 \mathrm{~h}$ and $24 \mathrm{~h}$. Ion spectrum of 2,3-DHB in negative ESI mode was identical to those of the standard. Based on this chromatograms it could be concluded that the highest amount of 2,3-DHB was determined after $1 \mathrm{~h}$ in the presence of $P$. stutzeri and A. xylosoxidans. The rate of biphenyl cleavage seems to be
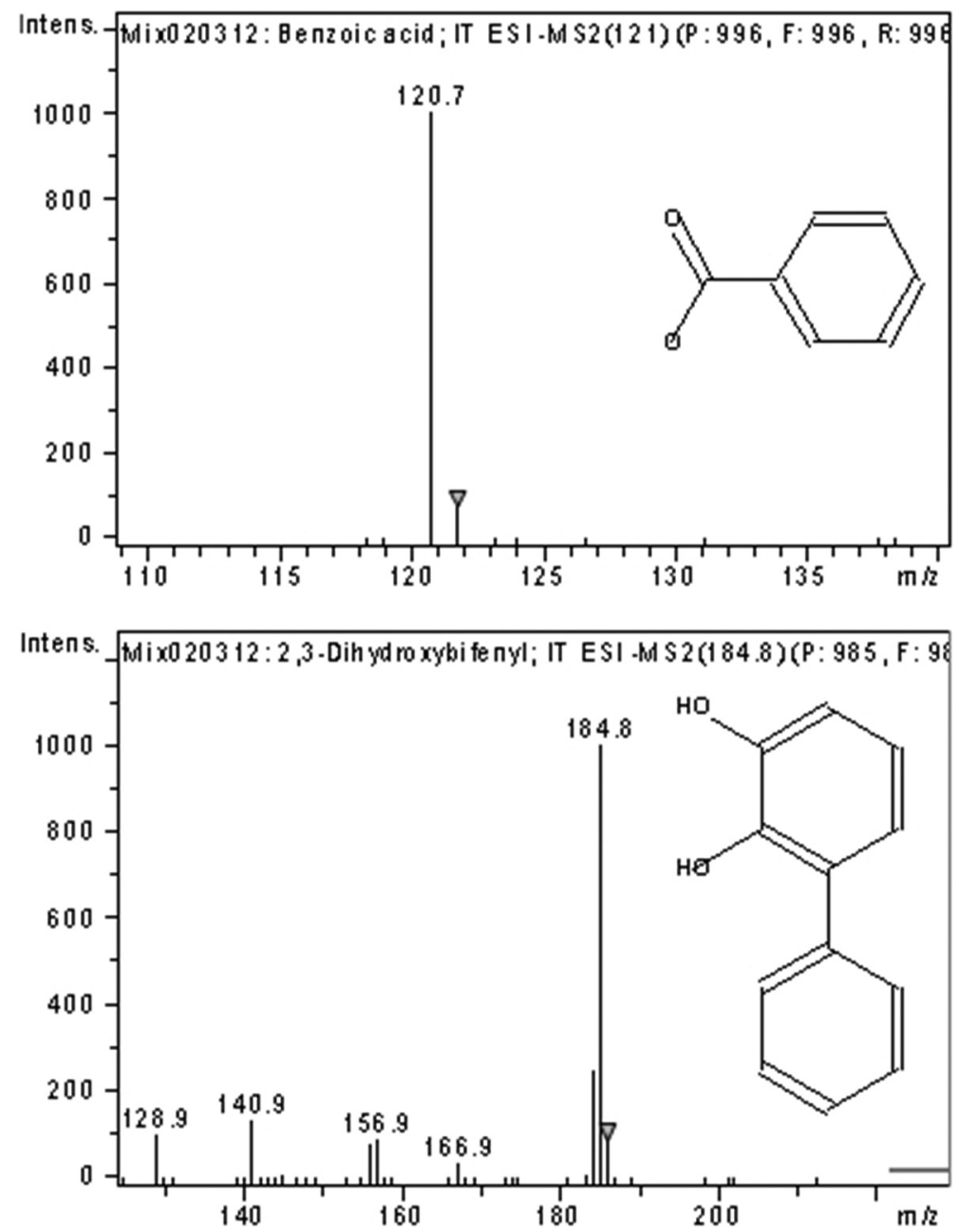

Fig. 4 Electrospray ionization (ESI-) mass spectra of benzoic acid and 2,3-DHB. 

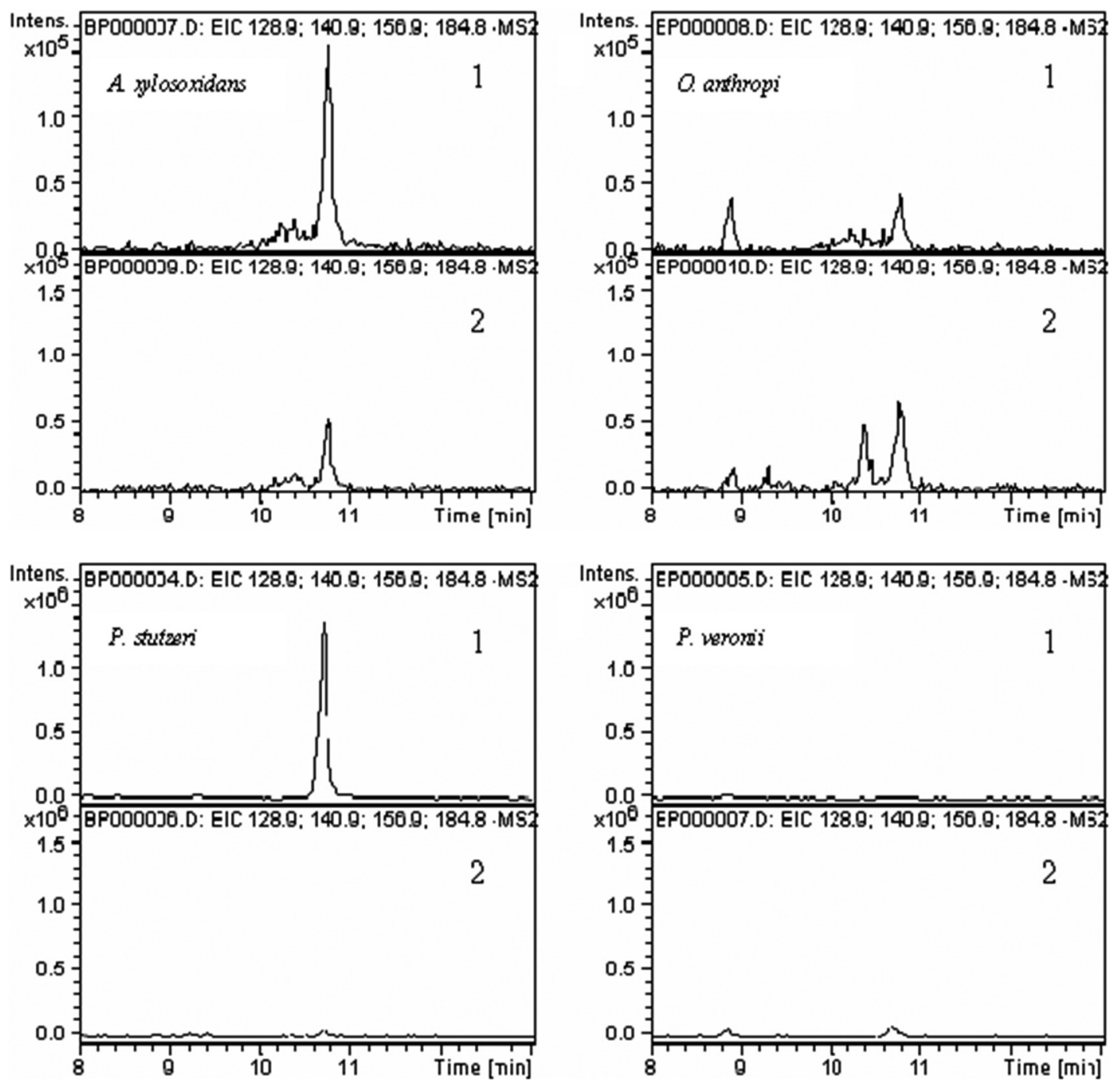

Fig. 5 The fragments of the ion LC-MS chromatogram of 2,3-DHB ( $\mathrm{RT}=10.8 \mathrm{~min}$ ) produced from biphenyl by A. xylosoxidans, O. anthropi, P. stutzeri, and P. veronii after $1 \mathrm{~h} \mathrm{(1)}$ and $24 \mathrm{~h}(2)$.

faster in the case of two abovementioned strains compared to $O$. anthropi and $P$. veronii, where the formation of 2,3-DHB was detectable in a significant amount only after $24 \mathrm{~h}$. The difference in 2,3-DHB amount in the medium with $O$. anthropi after $1 \mathrm{~h}$ and $24 \mathrm{~h}$ was minor. This fact indicates the slower biphenyl transformation than with A. xylosoxidans or $P$. stutzeri. The transformation of biphenyl may be continuous throughout $24 \mathrm{~h}$ or may start in a higher extent after $24 \mathrm{~h}$. According to Fig. 5 it may be concluded that the transformation of biphenyl into benzoic acid lasted more than $24 \mathrm{~h}$. On the other hand, biphenyl fission by $P$. veronii starts after $24 \mathrm{~h}$ because none significant amount of 2,3-DHB or benzoic acid were detected within the experiment. The fastest biphenyl transformation was observed in the presence of $P$. stutzeri.

Fig. 6 shows the formation of benzoic acid from biphenyl or 2,3-DHB after $1 \mathrm{~h}$ and $24 \mathrm{~h}$ from their addition. The extent of formation of benzoic acid by $P$. stutzeri seems to be similar when either of the initial compounds has been used (Fig. 6). The detected amount of this acid was similar after $1 \mathrm{~h}$ and $24 \mathrm{~h}$. This indicates the continuous formation of benzoic acid. A. xylosoxidans transformed significant amount of biphenyl into 2,3-DHB within $1 \mathrm{~h}$ and continued with its transformation into the benzoic acid. According to the quick transformation of biphenyl into 2,3-DHB by the strain, it seems that complete transformation of biphenyl into benzoic acid could take less than $24 \mathrm{~h}$. This assumption can be supported by the production of higher amount of benzoic acid $1 \mathrm{~h}$ after 2,3-DHB addition compared to the amount identified after $24 \mathrm{~h}$. The total conversion of biphenyl after $24 \mathrm{~h}$ was more than $80 \%$. The production of benzoic acid from biphenyl by $O$. anthropi was low and may increase after $24 \mathrm{~h}$. This correlates with the slow biphenyl transformation into 2,3-DHB. According to Fig. 5 and Fig. 6, it seems that complete biphenyl 

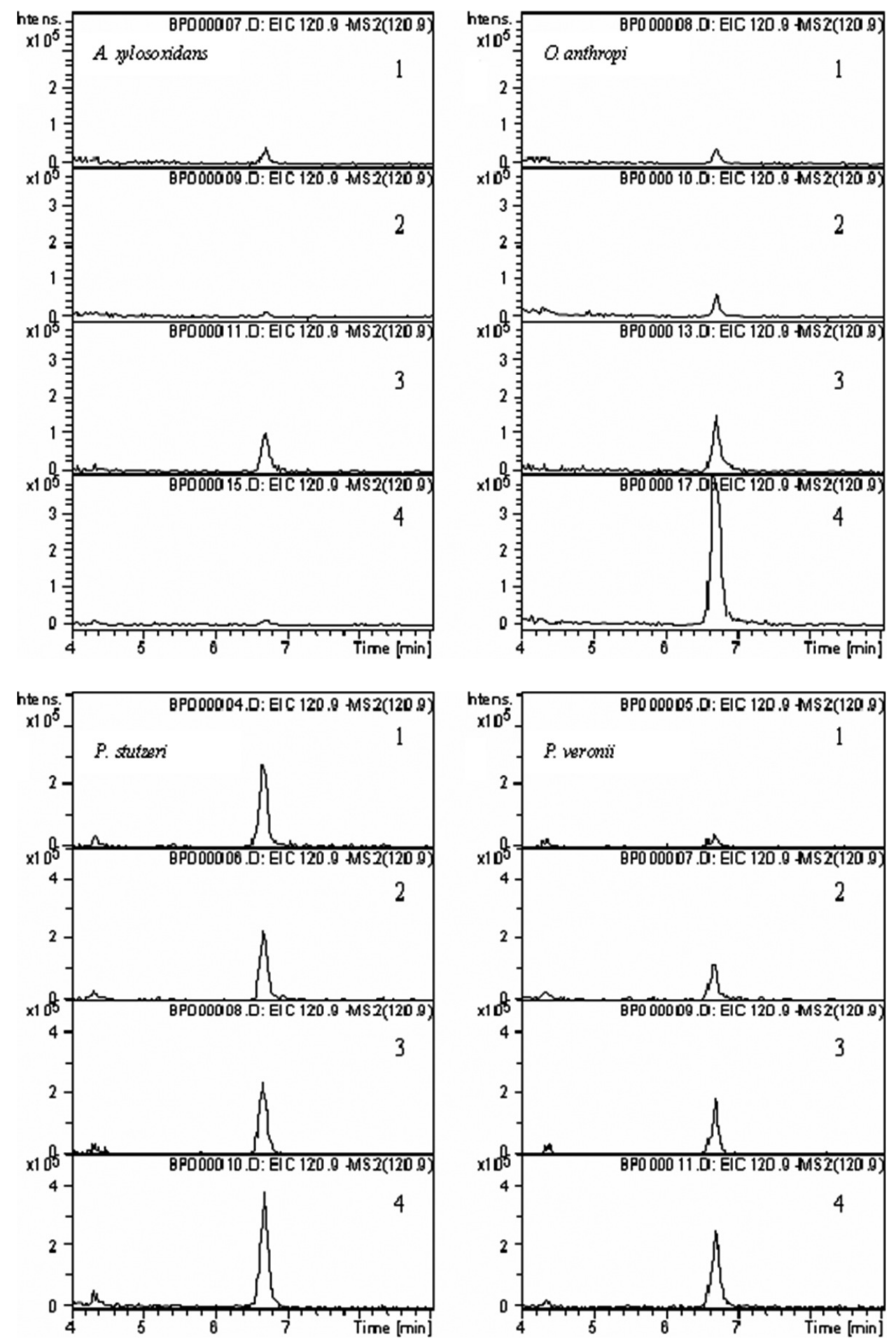

Fig. 6 The fragments of the ion LC-MS chromatogram of benzoic acid produced from biphenyl in the presence of A. xylosoxidans, O. anthropi, P. stutzeri, and P. veronii after $1 \mathrm{~h} \mathrm{(1)} \mathrm{and} 24 \mathrm{~h}$ (2) and from 2,3-DHB after $1 \mathrm{~h} \mathrm{(3)}$ and $24 \mathrm{~h} \mathrm{(4).}$

transformation by $O$. anthropi and $P$. veronii probably lasted more than $24 \mathrm{~h}$ because of the long time of biphenyl transformation into 2,3-DHB and $24 \mathrm{~h}$ transformation of 2,3-DHB into benzoic acid. The total conversion of biphenyl after $24 \mathrm{~h}$ did not exceed $40 \%$.

Our results indicate that both strains isolated from long-term PCB-contaminated soil - A. xylosoxidans and $P$. stutzeri showed the highest degradation rate of biphenyl into benzoic acid. Luo et al. (2008) claimed that strains naturally present in soil have higher adaptation to diverse types of aromatic compounds. This was explained with the greater plant deposition of aromatic rich lignin and humic substances in soils vs. river sediments. Our results confirmed this thesis. 


\section{Conclusions}

A. xylosoxidans and P. stutzeri, isolated from longterm PCB-contaminated soil revealed the highest biphenyl degradation efficiency. Some unusual degradation products of biphenyl were detected on GC-MS. The presence of acetophenone indicates more rarely 3,4-dioxygenase bacterial degradation pathway instead of more known 2,3-dioxygenase pathway. Both bacterial isolates with the potential to degrade PCBs are thus promising for application in bioremediation technologies using bioaugmentation approach.

\section{Acknowledgement}

Authors gratefully acknowledge the financial support from the Slovak Grant Agency (grant No. 1/0734/12) of Ministry of Education, Science, and Sports of Slovak Republic. This work was also supported by the Slovak Research and Development Agency under the contract No. APVV-0656-12.

\section{References}

Abramowicz DA (1990) Critical Reviews in Biotechnology 10: $241-251$.

Bedard DL, Haberl ML, May RJ, Brennan MJ (1987) Applied and Environmental Microbiology 53 (5): 1103-1112.

Brázová T, Hanzelová V, Miklisová D (2012) Parasitology Research 111: 779-786.

Chong NM, Chang CS, Tsai SC (2012) Environmental Science and Pollution Research 19: 3276-3281.

Dercová K, Čičmanová J, Lovecká P, Demnerová K, Macková M, Hucko P, Kušnír P (2008) International Biodeterioration and Biodegradation 62: 219-225.

Dercová K, Vrana B, Baláž Š, Sándorová A (1996) Journal of Industrial Microbiology 16: 325-329.

Dudášová $H$, Lukáčová L, Murínová S, Puškárová A, Pangallo D, Dercová K (2014) Journal of Basic Microbiology doi: 10.1002/jobm.201200369 (in press).

Field JA, Sierra-Alvarez R (2008) Environmental Pollution 155: 1-12.

Furukawa K, Yasukochi Y, Kikuchi Y, Nagata Y, Kimbara K, Horiuchi H, Takagi M, Yano K (1994) Biochemical and Biophysical Research Communications 202: $850-856$.

Furukawa K, Fujihara H (2008) Journal of Bioscience and Bioenginering 105(5): 433-449.

Komancová M, Jurčová I, Kochánková L, Burkhard J (2003) Chemosphere 50: 537-543.

Langer P, Kočan A, Tajtáková M, Drobná B, Chovancová J, Rádiková Ž, Ukropec J, Hučková M, Imrich R, Šofčíková E, Gašperíková D, Bergman A, HertzPicciotto I, Trnovec T, Klimeš I (2012) Monitor Medicíny SLS 3-4: 5-12.

Luo W, Dángelo EM, Coyne MS (2008) Soil Biology and Biochemistry 39: 735-743.

Mrozik A, Piotrowska-Seget Z (2010) Microbiology Research 165(5): 363-375.

Ohtsubo Y, Nagata Y, Kimbara K, Takagi M, Ohta A (2000) Gene 256: 223-228.

Murínová S, Dercová K, Dudášová H (2014) International Biodeterioration and Biodegradation 91: $52-59$.

Petrić I, Hršak D, Fingler S, Vončina E, Ćetković H, Kilar AB, Kolić NU (2007) Food Technology and Biotechnology 45(1): 11-20.

Seeger M, Timmis KN, Hofer B (1995) Applied and Environmental Microbiology 61(7): 2654-2658.

Sierra I, Valera JL, Marina ML, Laborda F (2003) Chemosphere 53: 609-618.

Sondossi M, Sylvestre M, Ahmad D (1992). Applied and Environmental Microbiology 58: 485-495.

Sylvestre M (1995) International Biodeterioration and Biodegradation 53: 189-211.

Tandlich R, Vrana B, Payne S, Dercová K, Balaz S (2011) Journal of Environmental Science and Health A 46(4): $1-8$.

Tříska J, Kuncová G, Macková M, Nováková H, Paasivirta J, Lahtiperä M, Vrchotová N (2004) Chemosphere 54: $725-733$.

Tu C, Teng Y, Luo Y, Li X, Sun X, Li Z, Liu W, Christie P (2011). Journal of Hazardous Materials 186: 1438-1444.

Vrana B, Dercová K, Baláž Š, Ševčíková A (1996) World Journal of Microbiology and Biotechnology 12: 323-326.

Yagi O, Sudo R (1980) Journal Water Pollution Control Federation 82: 1035-1043.

Zorádová-Murínová S, Dudášová H, Lukáčová L, Čertík M, Šilharová K, Vrana B, Dercová K (2012) Applied Microbiology and Biotechnology 94: 1375-1385. 